\title{
SKRINING SENYAWA KIMIA DAN PENGARUH METODE MASERASI DAN REFLUKS PADA BIJI KELOR (Moringa oleifera, Lamk) TERHADAP RENDEMEN EKSTRAK YANG DIHASILKAN
}

\author{
Agung Abadi Kiswandono \\ Dosen Kopertis Wil I NAD-Sumut dpk Universitas Prima Indonesia (UNPRI) Medan \\ e-mail : $\underline{\text { nau_shila@yahoo.com }}$
}

\begin{abstract}
Chemical Compounds and Effect of Screening Method on Seeds maceration and refluxing moringa (Moringa oleifera, Lamk) to the yield Extract Generated
\end{abstract}

Studies had been conducted with the goal of identifying chemical compounds and compare the two methods of extraction, the maceration and reflux in moringa seeds (Moringa oleifera, Lamk) to the yield generated. The study was conducted by using the method of extraction and maceration reflux with solvent hexane and $80 \%$ methanol, and then the identification of classes of secondary metabolites phytochemical test done. Moringa seed samples had $11.6 \%$ moisture content. Yield produced by the reflux method using $n$-hexane solvent were $23.03 \%$ and $21.22 \%$ maceration method. While the $80 \%$ methanol solvent refluxing method had yield $6.16 \%$ and 5.26\% maceration method. Phytochemical test results on seed powder contained alkaloids and saponins. Phytochemical test results on seed extract reflux method was an alkaloid, hydroquinone phenols, flavonoids and saponins while the maceration method was a class of compounds alkaloids and saponins.

Keywords : Moringa oleifera, reflux, maceration, phytochemicals

\begin{abstract}
ABSTRAK
Telah dilakukan penelitian dengan tujuan mengidentifikasi senyawa kimia dan membandingkan dua metode ekstraksi, yaitu maserasi dan refluks pada biji kelor (Moringa oleifera, Lamk) terhadap rendemen yang dihasilkan. Penelitian dilakukan dengan menggunakan metode ekstraksi maserasi dan refluks dengan pelarut heksana dan metanol 80\%, kemudian identifikasi golongan senyawa metabolit sekunder dilakukan dengan uji fitokimia. Sampel biji kelor memiliki kadar air 11,6\%. Rendemen yang dihasilkan dengan metode refluks menggunakan pelarut $n$-heksana adalah $23,03 \%$ dan metode maserasi $21,22 \%$. Sedangkan dengan pelarut Metanol $80 \%$ metode refluks mempunyai rendemen 6,16\% dan metode maserasi 5,26\%. Hasil uji fitokimia pada serbuk biji mengandung alkaloid dan saponin. Hasil uji fitokimia pada ekstrak biji menggunakan metode refluks adalah alkaloid, fenol hidrokuinon, flavonoid, dan saponin sedangkan dengan metode maserasi adalah senyawa golongan alkaloid dan saponin.
\end{abstract}

Kata kunci : Moringa oleifera, refluks, maserasi, fitokimia

\section{PENDAHULUAN}

Indonesia sangat kaya akan tumbuhan yang mengandung metabolit sekunder yang dapat dijadikan sebagai sumber obat tradisional oleh masyarakat. Pencarian obat baru dalam upaya menyembuhkan berbagai penyakit mendorong banyak peneliti untuk berusaha menemukan dengan memanfaatkan tumbuh-tumbuhan. Diantara tumbuhan yang berpotensi sebagai obat tradisional adalah tumbuhan kelor atau Moringa oleifera L (Siddhuraju dan Beccer, 2003). Menurut penelitian Sato, et al. (2002) pada 20 tumbuhan dari Asia selatan dan Asia Tenggara, Moringa oleifera L termasuk dalam dua besar tumbuhan yang mempunyai aktivitas antioksidan tertinggi.

Ekstraksi atau pemisahan senyawa kimia dari sumber tanaman merupakan awal proses isolasi senyawa bioaktif yang berada pada tumbuhan, baik pada biji, biji, akar ataupun batang (Sidik, 1997). Pada proses pemisahan senyawa bioaktif, pemilihan metode pemisahan senyawa merupakan hal yang penting untuk diperhatikan, karena pada proses pemisahan ini akan ditentukan berapa besar rendemen yang dihasilkan. 


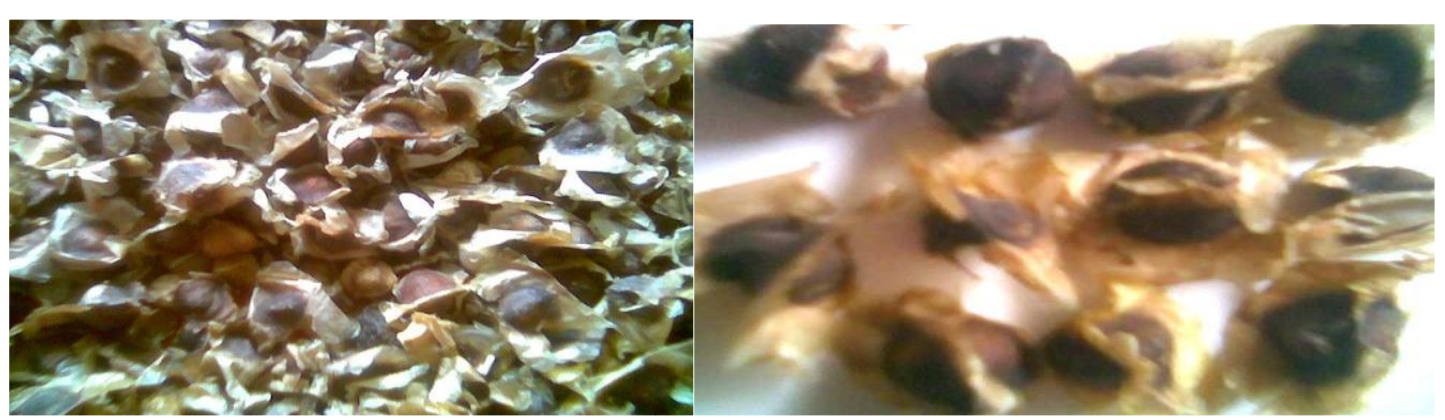

Gambar 1. Biji Tumbuhan Kelor

Metode pemisahan pada ekstraksi pelarut menggunakan prinsip kelarutan. Prinsip kelarutan adalah like dissolve like, yaitu pelarut polar akan melarutkan senyawa polar dan pelarut non polar akan melarutkan senyawa non polar (Simanjuntak, 1988). Beberapa pelarut organik yang sering digunakan sebagai ekstraktan seperti benzena, toluena, petroleum eter, metilenklorida, klorofrom, karbon tetraklorida, etil asetat dan dietil eter. Dalam pemilihan pelarut, hal-hal yang perlu dipertimbangkan adalah selektifitas, sifat racun dan kemudahannya untuk diuapkan. Alkohol merupakan pelarut yang baik untuk ekstraksi pendahuluan (Harborne, 1996).

Ekstraksi digunakan untuk memperoleh kandungan senyawa kimia yang larut pada pelarut. Ada beberapa macam ekstraksi yang biasa digunakan pada proses pemisahan senyawa bioaktif dari tumbuhan dalam rangka mengetahui rendemen yang akan dihasilkan, yakni ekstraksi cara dingin yang terdiri dari maserasi, perkolasi dan sokletasi serta ekstraksi cara panas, yakni dengan cara refluks.

Metode maserasi digunakan untuk mengekstrak sampel yang relatif tidak tahan panas. Metode ini dilakukan hanya dengan merendam sampel dalam suatu pelarut dalam jangka waktu tertentu, biasanya dilakukan selama 24 jam tanpa menggunakan pemanasan. Kelebihan metode ini diantaranya adalah tidak memerlukan peralatan yang rumit, relatif murah, dapat menghindari penguapan komponen senyawa karena tidak menggunakan panas, sedangkan kelemahannya adalah memerlukan waktu yang lama dan pelarut yang banyak sehingga tidak efisien (Meloan, 1999).

Metode refluks digunakan untuk mengekstrak sampel yang relative tahan panas. Metode ini dilakukan dengan cara menggodok sampel dalam suatu pelarut yang diletakan dalam wadah dan dilengkapi dengan kondensor dengan jangka waktu lebih cepat, biasanya 3-7 jam. Kelebihan metode ini adalah waktunya lebih singkat, terjadi kontak langsung dengan pelarut secara terus menerus, dan pelarut yang digunakan lebih sedikit sehingga efektif dan efisien.

Penelitian ini bertujuan untuk membandingan dua proses pemisahan atau ekstraksi senyawa kimia yang terkandung pada biji Moringa oleifera L, yakni dengan cara dingin (menggunakan proses maserasi) dan dengan cara panas (menggunakan proses refluks).

\section{METODE PENELITIAN}

\section{Bahan}

Sampel biji kelor diambil pada bulan April dari Nusa Tenggara Barat. Zat kimia yang dipakai semua pure analysis, yaitu metanol, heksana, satu set pereaksi uji fitokimia (terdiri dari uji alkaloid, terpenoid, flavonoid, saponin dan tanin), kertas saring, akuades, aluminium foil, kapas bebas lemak dan tissue.

\section{Peralatan}

Alat yang digunakan adalah satu set alat - alat gelas, alat ekstraksi refluks dan maserasi, oven, labu penguap putar, blender, neraca analitik, desikator, 
refrigerator dan satu set alat untuk uji fitokimia.

\section{Prosedur Kerja}

Sampel biji kelor yang didapatkan, kemudian dibersihkan dari kotoran-kotoran dan dikeringkan di udara terbuka. Sampel yang telah kering lalu dihaluskan dengan menggunakan blender, kemudian dihitung kadar airnya dan dilakukan proses ekstraksi cara dingin dan panas.

\section{Penentuan Kadar Air}

Penentuan kadar air sampel dengan cara sejumlah berat sampel kering dimasukkan ke dalam cawan porselin yang telah diketahui bobot kosongnya. Kemudian cawan tersebut dipanaskan di dalam oven pada suhu $105{ }^{\circ} \mathrm{C}$ selama 3 jam. Setelah itu didinginkan di dalam desikator dan ditimbang untuk mengetahui bobot keringnya, pemanasan sampel diulang sampai diperoleh bobot yang konstan. Kadar air ditentukan dengan rumus Kadar Air $(\%)=[(B-C) /(B-A)]$ $x 100$

Keterangan :

A : Berat cawan kosong

B : Berat cawan + berat sampel

C : Berat akhir sampel

\section{$\underline{\text { Ekstraksi Dingin (Maserasi) }}$}

Sebanyak 20 - 25 g sample kering yang telah dihaluskan dimaserasi dengan heksana sampai bebas lemak. Ekstraksi dilakukan sebanyak 4 kali ulangan. Ekstrak yang dihasilkan disaring, kemudian filtratnya di pekatkan dengan menggunakan labu penguap putar pada suhu $40{ }^{\circ} \mathrm{C}$ sehingga diperoleh ekstrak kasar dan dihitung rendemennya. Ampasnya dikering anginkan lalu setelah kering, dimaserasi kembali dengan metanol $80 \%$ dengan cara yang sama seperti heksana. Filtrat yang dihasilkan lalu dipekatkan dan didapatkan ekstrak kasar dan dihitung rendemennya.

\section{Ekstraksi Panas (Refluks)}

Sebanyak 20 - 25 g sample kering yang telah dihaluskan dimasukkan kedalam labu bulat, ditambahkan heksana secukupnya dan direfluks selama 7 jam. Ekstraksi dilakukan sebanyak 4 kali ulangan. Ekstrak yang dihasilkan disaring, kemudian filtratnya di pekatkan dengan menggunakan labu penguap putar pada suhu $40{ }^{\circ} \mathrm{C}$ sehingga diperoleh ekstrak kental dan dihitung rendemennya. Ampasnya dikering anginkan lalu setelah kering, direfluks kembali menggunakan metanol $80 \%$ dengan cara yang sama seperti heksana. Filtrat yang dihasilkan lalu dipekatkan sehingga didapatkan ekstrak kasar dan dihitung rendemennya.

Rendemen yang dihasilkan dari kedua metode ekstraksi tersebut lalu di uji dengan uji t. Untuk menarik kesimpulan dapat dilihat dari nilai-t (t hitung) yang kemudian dibandingkan dengan nilai ttabel. Jika nilai t hitung > dari t-tabel maka kesimpulannya tolak $\mathrm{H}_{0}$ artinya terdapat perbedaan diantara kedua metode tersebut.

Ekstrak metanol $80 \%$ yang dihasilkan dari proses maserasi dan refluks serta sampel serbuk biji kelor diuji fitokimia untuk mengetahui golongan senyawa kimianya. Uji fitokimia yang dilakukan meliputi uji kualitatif untuk alkaloid, triterpenoid-steroid, saponin, flavonoid, dan tanin.

\section{HASIL DAN PEMBAHASAN}

Bagian tumbuhan yang digunakan dalam penelitian ini adalah biji. Biji kelor yang sudah kering lalu dihaluskan dengan menggunakan blender. Tujuannya adalah untuk memudahkan kontak dengan pelarut sehingga pada tahap ekstraksi, interaksi antara pelarut pengekstrak dengan sampel yang diekstraksi menjadi lebih efektif dan pelarut pengekstrak akan lebih mudah mengambil zat-zat yang terkandung dalam sampel.

Sampel yang digunakan pada penelitian ini merupakan bahan yang berasal dari tumbuh - tumbuhan, sehingga sampel mengandung air yang jumlahnya relatif tinggi. Oleh karena itu, dalam tahap 
persiapan sampel harus dilakukan penentuan kadar air yang terkandung dalam sampel. Kadar air merupakan parameter penting dalam bahan pangan, karena akan mempengaruhi daya tahan bahan pangan terhadap serangan atau aktivitas mikroorganisme. Bahan pangan yang memiliki kadar air tinggi lebih mudah rusak karena akan menjadi media yang kondusif bagi pertumbuhan mikroorganisme.

Kadar air ditetapkan dengan cara gravimetri, yaitu diperoleh dengan cara menghitung bobot bahan sebelum dan sesudah dikeringkan pada temperatur di atas titik didih air, sehingga diharapkan semua air akan menguap pada suhu tersebut dan pada periode waktu tertentu (Harjadi, 1986).

Berdasarkan penentuan kadar air yang telah dilakukan (tabel 1), didapatkan bahwa sampel biji mempunyai kadar air di atas $10 \%$, yakni $11,6 \%$. Hal yang sama, pernah didapatkan oleh Budiman (2001), yakni $11,9 \%$ dengan sampel kering giling dari tumbuhan A. Sacrorum Ledeb, Wulandari (2005) memperoleh 13,3\% dengan sampel buah mahkota dewa, dan Putri (2004) memperoleh 8,4 - 11,1\% dengan sampel kulit buah kakao. Menurut Winarno (1997), sampel yang baik untuk disimpan dalam jangka panjang adalah jika kadar air sampel kurang dari 10\%. Kadar air dalam penelitian ini rata-rata diatas $10 \%$, oleh karena itu sampel tidak bisa digunakan dalam jangka waktu yang lama karena memungkinkan timbulnya jamur. Untuk menghindari hal tersebut maka sampel disimpan di dalam freezer.

\section{Pemisahan Senyawa Kimia dan Uji Fitokimia}

Pemisahan golongan senyawa kimia pada penelitian ini menggunakan metode maserasi dan refluks. Mekanisme metode maserasi adalah proses difusi pelarut ke dalam dinding sel tumbuhan untuk mengekstrak senyawa-senyawa yang ada dalam tumbuhan tersebut. Metode maserasi digunakan untuk mengekstrak senyawa yang kurang tahan terhadap panas, biasanya digunakan untuk sampel yang belum diketahui karakterisasi senyawanya, sedangkan metode refluks menggunakan efek panas untuk membantu proses difusi pelarut ke dalam dinding sel tumbuhan.

Pelarut yang digunakan pada masing-masing sampel adalah heksana dan metanol $80 \%$. Senyawa yang akan terbawa pada proses ini adalah senyawasenyawa yang memiliki polaritas yang sesuai dengan pelarut yang digunakan. Kemudian larutan yang dihasilkan (gambar 2) di kentalkan menggunakan labu penguap putar untuk mendapatkan ekstrak kental, kemudian dihitung rendemennya. Ampas dari ekstraksi lalu dikeringkan dan di lakukan ekstraksi kembali menggunakan pelarut matanol $80 \%$, dengan perlakuan yang sama, larutan di kentalkan dan dihitung rendemennya. Setelah diperoleh ekstrak kasar metanol $80 \%$.

Pelarut heksana adalah pelarut non polar, sehingga senyawa - senyawa yang larut juga berfsifat non polar, sedangkan metanol $80 \%$ adalah pelarut yang bersifat polar, digunakan untuk menarik senyawasenyawa yang bersifat polar. Pemisahan pertama terhadap sampel digunakan pelarut heksana dengan tujuan untuk memisahkan senyawa-senyawa non polar termasuk lemak yang terkandung pada sampel. Setelah diperoleh ekstrak kasar metanol $80 \%$, lalu di lakukan uji fitokimia.

Dalimartha (2003) menyatakan bahwa toksisitas tanaman berhubungan dengan metabolit sekunder yang terkandung di dalamnya. Oleh karena itu uji fitokimia secara kualitatif dilakukan sebagai uji awal untuk mengetahui keberadaan senyawa kimia spesifik. Uji fitokimia bertujuan untuk melakukan keberadaan terhadap beberapa senyawa kimia yang terkandung dalam sampel. Uji fitokimia yang dilakukan pada serbuk biji, serta pada ekstrak metanol $80 \%$ biji adalah uji alkaloid, flavonoid, steroid, triterpenoid, tanin, fenol hidrokuinon dan saponin. 
Tabel 1. Pengukuran Kadar Air pada Serbuk Biji Kelor

\begin{tabular}{|c|c|c|c|c|}
\hline \multirow[b]{2}{*}{ Sampel } & \multicolumn{3}{|c|}{ Berat (gram) } & $\begin{array}{c}\text { Kadar } \\
\text { Air }(\%)\end{array}$ \\
\hline & Cawan kosong & $\begin{array}{c}\text { Cawan }+ \text { Sampel } \\
\text { (sebelum } \\
\text { pengeringan) }\end{array}$ & $\begin{array}{c}\text { Cawan }+ \text { Sampel } \\
(\text { setelah } \\
\text { pengeringan) }\end{array}$ & \\
\hline & A & B & $\mathrm{C}$ & \\
\hline Biji 1 & 1,262 & 3,292 & 3,058 & 11,527 \\
\hline Biji 2 & 0,757 & 2,765 & 2,532 & 11,604 \\
\hline $\begin{array}{l}\text { Rata-rata } \\
\text { Kadar air }\end{array}$ & \multicolumn{4}{|c|}{$11,6 \%$} \\
\hline
\end{tabular}

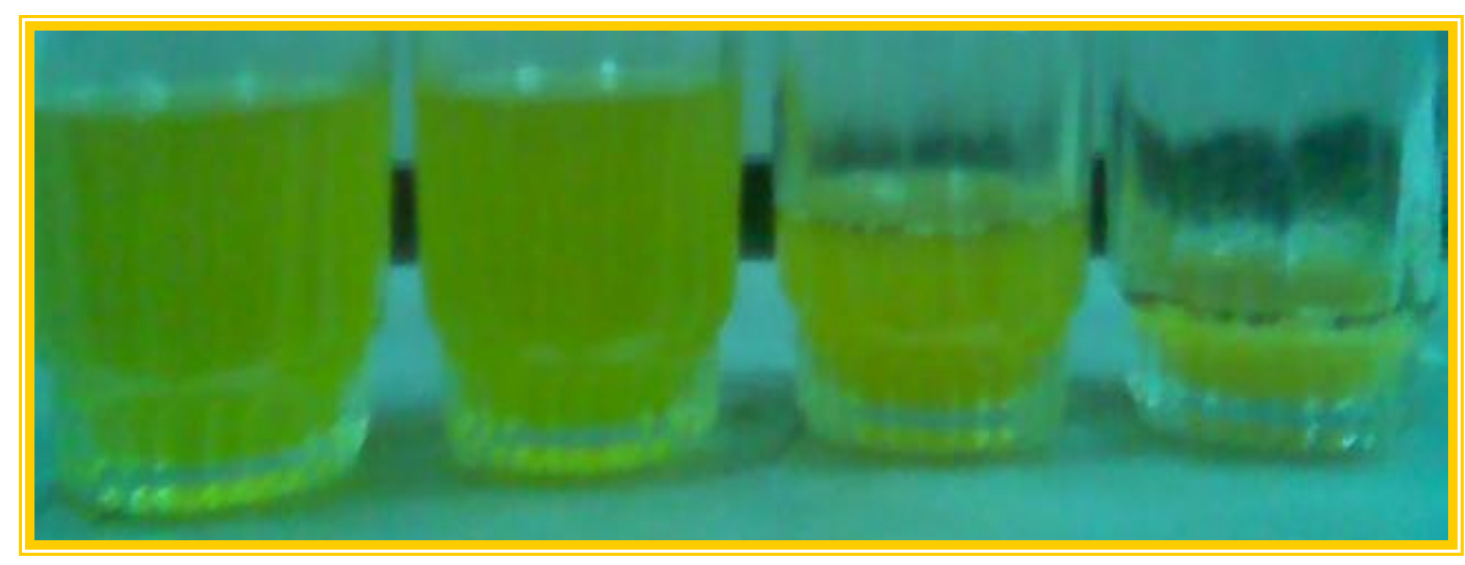

Gambar 2. Warna Ekstrak Biji.

Adanya alkaloid pada sampel ditunjukkan dengan terdapatnya endapan putih dengan pereaksi Mayer, endapan merah jingga dengan pereaksi Dragendroff, dan endapan coklat dengan pereaksi Wagner. Adanya fenol hidrokuinon ditunjukkan dengan warna merah saat penambahan $\mathrm{NaOH} 10 \%$. Adanya steroid ditunjukkan dengan warna hijau pada lapisan eter yang ditambahkan dengan pereaksi Liebermann-burchard. Adanya tanin ditunjukkan atau ditandai dengan adanya warna biru tua atau hijau kehitaman, sedangkan adanya saponin pada sampel ditunjukkan dengan terbentuknya busa yang stabil pada filtrat yang ditutup serlama 10 menit pada tabung reaksi.
Hasil uji fitokimia terhadap sampel serbuk biji kelor dapat dilihat pada Tabel 2. Dari tabel tersebut terlihat bahwa, serbuk biji kelor hanya mengandung alkaloid dan saponin. Senyawa alkaloid pada serbuk biji mempunyai intensitas yang besar dibandingkan saponin. Hasil uji fitokimia terhadap ekstrak biji menggunakan metode refluks, dan maserasi seperti pada tabel 3. Pada tabel 3 terlihat bahwa, intensitas golongan senyawa alkaloid dengan metode refluks lebih rendah dibandingkan dengan menggunakan metode maserasi, demikian pula dengan saponin. 
Tabel 2. Hasil Uji Fitokimia Serbuk Biji Kelor

\begin{tabular}{ll}
\hline Uji Fitokimia & Sebuk Biji \\
\hline Alkaloid & ++++ \\
Fenol hidrokuinon & - \\
Flavonoid & - \\
Steroid & - \\
Triterpenoid & - \\
Tanin & - \\
Saponin & ++ \\
\hline
\end{tabular}

Keterangan :

- : negatif (tidak terdapat senyawa yang diuji)

+ : positif menyatakan intensitas warna/ endapan

Hal ini menunjukkan bahwa, ada beberapa senyawa alkaloid tidak tahan terhadap panas, sehingga mengakibatkan intensitasnya berkurang setelah dilakukan pemisahan dengan metode refluks. Tetapi disisi lain, bahwa dengan metode refluks, senyawa metabolit sekunder yang negatif (-) pada serbuk biji, kemudian (+) setelah dilakukan refluks, yakni senyawa fenol hidrokuinon dan flavonoid walaupun intensitasnya kecil. Hal ini disebabkan, bahwa pemisahan pertama yang dilakukan dengan pelarut non polar (heksana), dapat membantu memunculkan golongan senyawa-senyawa tersebut, karena heksana dapat melarutkan lemak, minyak dan senyawa - senyawa non polar lainnya yang dapat mengganggu munculnya golongan senyawa tersebut pada saat pengujian fitokimia serbuk biji.

Hasil pengujian terhadap sampel menunjukkan, bahwa biji kelor mengandung alkaloid, fenol hidrokuinon, flavonoid, dan saponin sehingga biji kelor berpotensi sebagai antioksidan (Pratt and Hudson 1990, Benabdesselam et.al. 2007). Beberapa peneliti juga menyatakan, bahwa tumbuhan kelor atau Moringa oleifera L adalah salah satu tumbuhan yang berpotensi sebagai antioksidan (Siddiq et.al. 2005, Chumark et al. 2007, Sato et.al., 2002, Kumar dan Pari, 2003). Senyawa tersebut berperan sebagai antioksidan dengan cara menghambat peroksida lipid sehingga dapat melindungi tubuh dari penyakit kanker.

Sampel biji kelor juga berpotensi sebagai penurun kolesterol dan dapat memperkecil resiko arteroskeloris pada diabetes karena mengandung saponin (Rafi, 2003) juga berpotensi sebagai penurun kadar glukosa darah karena mengandung senyawa bioaktif alkaloid (Hermawan, 2002).

\section{Rendemen Senyawa Kimia yang dihasilkan}

Rendemen adalah perbandingan produk akhir yang diperoleh terhadap bahan baku yang digunakan. Nilai rendemen yang diperoleh berdasar berat kering bahan baku. Rendemen produk berkaitan dengan metode ekstraksi yang dipakai untuk memisahkan senyawa kimia.

Metode ekstraksi yang digunakan pada penelitian ini adalah maserasi (ekstraksi dingin) dan refluks (ekstraksi panas). Hal ini dilakukan dengan tujuan untuk melihat pengaruh proses ekstraksi yang berbeda-beda terhadap rendemen dan golongan senyawa kimia yang dihasilkan.

Rendemen yang diperoleh dari hasil ekstraksi pada sampel biji (tabel 4) menunjukkan bahwa metode refluks dengan pelarut heksana memiliki rendemen lebih besar yakni 23,030\% dibandingkan metode maserasi dengan rendemennya hanya $21,221 \%$. Hal yang sama juga terjadi dengan pelarut metanol $80 \%$. Rendemen yang diperoleh dari hasil ekstraksi pada sampel biji (Tabel 5) menunjukkan bahwa metode refluks mempunyai rendemen yang lebih besar, yakni $6,157 \%$ dibandingkan metode maserasi yang hanya menghasilkan $5,256 \%$.

Pada tabel 4, 5 dan gambar 3 terlihat bahwa perbedaan rendemen yang diperoleh pada ekstraksi biji kelor dengan metode refluks dan maserasi menggunakan pelarut heksana adalah $1,808 \%$ dan dengan menggunakan pelarut Metanol $80 \%$ adalah $0,901 \%$. 
Tabel 3. Hasil uji Fitokimia dengan Metode Refluks dan Maserasi Menggunakan Pelarut Metanol 80\%

\begin{tabular}{lcc}
\hline \multicolumn{1}{c}{ Uji Fitokimia } & Metode Refluks & Metode Maserasi \\
\hline Alkaloid & ++ & +++ \\
Fenol hidrokuinon & + & - \\
Flavonoid & + & - \\
Steroid & - & - \\
Triterpenoid & - & - \\
Tanin & - & - \\
Saponin & + & ++ \\
\hline
\end{tabular}

Tabel 4. Rendemen pada Sampel Biji dengan Pelarut Heksana.

\begin{tabular}{|c|c|c|c|}
\hline \multirow{2}{*}{ Sampel Biji } & \multicolumn{2}{|c|}{ Rendemen (\%) } & \multirow{2}{*}{$\begin{array}{c}\text { Selisih } \\
\text { (ke dua metode) }\end{array}$} \\
\hline & Metode Refluks & Metode Maserasi & \\
\hline Ulangan 1 & 22,792 & 20,359 & \\
\hline Ulangan 2 & 22,410 & 21,712 & \\
\hline Ulangan 3 & 23,360 & 21,568 & $1,808 \%$ \\
\hline Ulangan 4 & 23,556 & 21,247 & \\
\hline Rata-rata & 23,030 & 21,221 & \\
\hline
\end{tabular}

Tabel 5. Rendemen pada Sampel Biji dengan Pelarut Metanol 80\%

\begin{tabular}{lccc}
\hline \multirow{2}{*}{ Sampel Biji } & \multicolumn{2}{c}{ Rendemen (\%) } & $\begin{array}{c}\text { Selisih } \\
\text { (ke dua metode) }\end{array}$ \\
\cline { 2 - 3 } & Metode Refluks & Metode Maserasi & \\
\hline Ulangan 1 & 5,885 & 4,920 & \\
Ulangan 2 & 5,852 & 5,334 & $0,901 \%$ \\
Ulangan 3 & 6,267 & 5,807 & \\
Ulangan 4 & 6,625 & 4,963 & \\
Rata-rata & 6,157 & 5,256 & \\
\hline
\end{tabular}

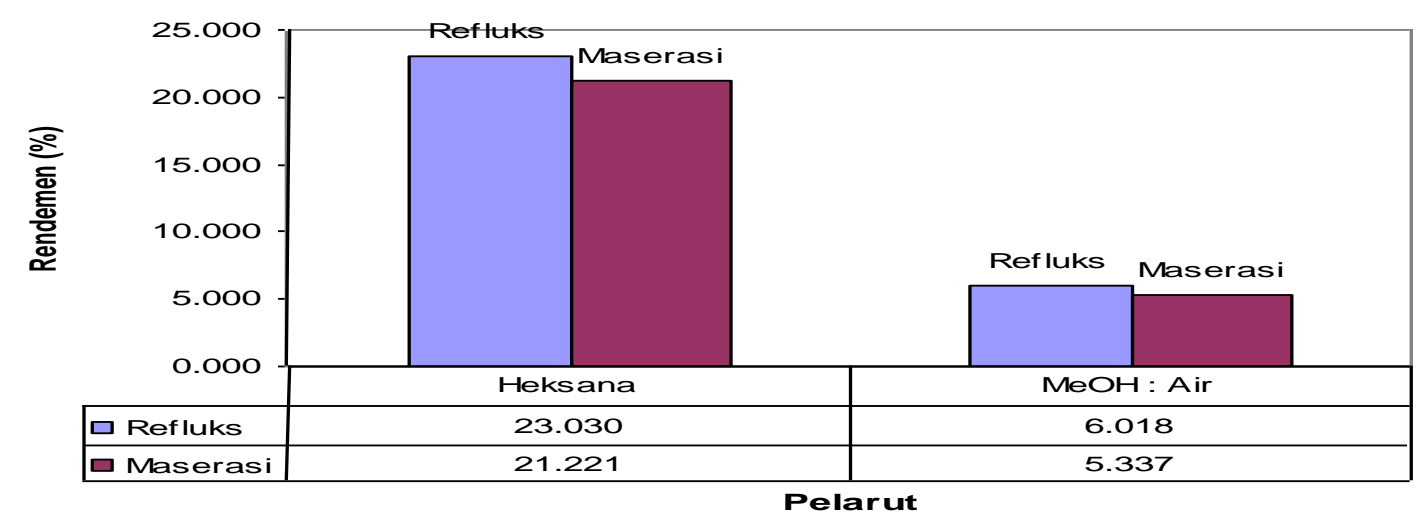

Gambar 3. Perbandingan Rendemen pada Sampel Biji Menggunakan Pelarut Heksana dan Metanol 80\% (MeOH : air, 4:1) dengan Metode Refluks dan Maserasi. 
Uji t antara metode refluks dan maserasi biji kelor menggunakan pelarut metanol $80 \%$ (Lampiran 2), dapat diketahui bahwa nilai-p dari uji adalah 0,172 . Karena nilai-p nya lebih besar dari taraf nyata $(\alpha) 5 \%$, maka kesimpulannya terima $\mathrm{H}_{0}$ artinya antara metode reflukheksana dan maserasi-heksana tidak berbeda nyata pada taraf nyata $5 \%$, atau untuk menarik kesimpulan dapat dilihat dari nilai-t ( $\mathrm{t}$ hitung), yakni nilai $\mathrm{t}$ hitung didapat sebesar 1,59 , sedangkan nilai ttabel dengan $\mathrm{df}=5$, dan $\alpha=5 \%$ adalah 2,571, karena nilai $\mathrm{t}$ hitung $<$ dari t-tabel maka kesimpulannya terima $\mathrm{H}_{0}$ artinya tidak terdapat perbedaan diantara kedua metode tersebut.

Secara uji statistik tidak terdapat perbedaan nyata antara metode refluks dan maserasi dengan menggunakan pelarut metanol $80 \%$, tetapi metode refluks, dari segi waktu memiliki efisiensi ekstraksi yang lebih singkat dibandingkan dengan metode maserasi. Proses ekstraksi dengan refluks memerlukan waktu $4 \times 2$ jam, sedangkan dengan maserasi memerlukan waktu sampai $3 \times 24$ jam. Kemudian dari segi pelarut yang digunakan, metode maserasi relatif menggunakan pelarut lebih banyak dibandingkan dengan metode refluks.

Metode refluks ataupun maserasi menggunakan pelarut heksana, secara rata-rata pada sampel biji dihasilkan rendemen yang lebih besar, dengan demikian dapat disimpulkan, bahwa pada biji kelor banyak terdapat senyawa metabolit sekunder yang bersifat nonpolar.

\section{KESIMPULAN}

Dari hasil penelitian dapat disimpulkan :

1. Kadar air rata-rata pada sampel biji $11,565 \%$.

2. Golongan senyawa kimia pada ekstrak biji dengan pelarut methanol $80 \%$ dengan refluks adalah alkaloid, phenol hidroquinin, flavonoid dan saponin, sedangkan dengan maserasi hanya alkaloid dan saponin.
3. Metode refluks dapat mengekstrak senyawa kimia lebih besar dari pada metode maserasi.

\section{UCAPAN TERIMA KASIH}

Ucapan terima kasih kepada Kopertis Wilayah I NAD-SUMUT yang telah membiayai penelitian ini. Terima kasih juga kepada Dewi Wulandari, MS., Dekan FMIPA Universitas Tri Karya Medan, DR. Dyah Iswantini, M.Agr. dosen Sekolah Pascasarjana Kimia IPB Bogor yang telah membimbing selama penelitian ini berlangsung.

\section{DAFTAR PUSTAKA}

Budiman, A. 2001. Senyawa Bioaktif Golongan Kumarin Artemisia Sacrorum Ledeb (Skripsi). Bogor : FMIPA. IPB.

Benabdesselam FM. Et.al. 2007. Antioxidant activities of alkaloid extracts of two Algerian species of Fumaria : Fumaria capreolata and Fumaria bastardii. ACG Publication Rec. Nat. Prod. 1:23 (2007) 28-35.

Chumark P et al. 2007. The in vitro and ex vivo antioxidant properties, hypolipidaemic and antiatherosclerotic activities of water extract of Moringa oleifera Lam. Leaves. Journal of Ethnopharmacology 116(2008) 439-446.

Dalimarta, S. 2003. Karakteristik Tumbuhan Obat di dalam Prosiding Seminar dan Pameran Nasional Tumbuhan Obat Indonesia XXIV. Darmaga, Bogor. Pusat Studi Biofarmaka IPB.

Harborne, J. B. 1996. Metode Fitokimia. Cara modern menganalisa Tumbuhan. Terjemahan Kosasih Patmawinata dan 
Iwang Soediro. Edisi ke 3. Bandung. Penerbit ITB.

Harjadi W. 1986. Ilmu Kimia Analitik dasar. Jakarta. PT Gramedia Pustaka Umum.

Hermawan, H. 2002. Isolasi dan Pencirian Senyawa Aktif dari Tumbuhan Anting-anting (Acalypha indica L.) yang Berpotensi Menurunkan Kadar Glukosa Darah. Bogor: FMIPA. IPB.

Hidayat MG. 2004. Perbandingan Metode Ekstraksi Flavonoid dan Terpenoid dari Sidaguri Serta Daya Inhibisi Ekstrak Terhadap Aktivitas Xantin Oxidase. (Skripsi) Bogor: FMIPA. IPB.

Kumar NA \& Pari L. 2003 Antioxidant Action of Moringa oleifera Lam. (Drumstick) Against Antitubercular Drugs Induced Lipid Peroxidation in Rats. Journal of Medicinal Food. 6(3): 255-259.

Meloan CE. 1999. Chemical Separation.New york: J. Willey.

Prat DE, BJF. Hudson. 1990. Natural Antioxidant not Exploited Commercially. Di dalam BJF Hudson . Editor Food Antioxidant. London. Elsevier Science.

Putri, LD. 2004. Pemisahan dan Pencirian Pektin Dari Kulit Buah Kakao (Skripsi). Bogor: FMIPA. IPB.

Rafi, M. 2003. Identifikasi Fisik dan Senyawa Kimia Pada Tumbuhan Obat Fokus Untuk Tumbuhan Obat Diabites
Melitus. Dalam makalah Pelatihan Tanaman Tradisional (swamedikasi) Pengobatan Penyakit Diabites Melitus. Bogor. Pusat Studi Biofarmaka. IPB.

Sato T et al. 2002, Evaluation of antioxidant activity of indigenous vegetables from South and Southeast Asia . JIRCAS Research Highlights.

Siddhuraju P, Becker K. 2003. Antioxidant Properties of Various Solvent Extract of Total Phenolic Constituents from Three Different Agroclimatic Origins of Drumstick Tree (Moringa oleifera Lam.). J. Agric. Food Chem. 51 (8) : 2144-2155.

Simanjuntak, P. 1988. Metode Isolasi dan Pemurnian Ekstrak Air dari Tumbuhan. Warta AKAB.

Sidik M. 1997. Antioksidan Alami Asal Tumbuhan. Prosiding Seminar Nasional Tumbuhan Obat Indonesia XII. ITB. Bandung.

Siddiq A et al. 2005. Antioxidant activity of different solvent extracts of Moringa oleifera leaves under accelerated storage of sunflower oil. Asian Journal of Plant Sciences 4(6) 630-635.

Wulandari, NDM. 2005. Perbandingan Metode Ekstraksi Buah Mahkota Dewa (Phaleria macrocarpa) dan Uji Toksisitas Subkronis Pada tikus Putih (Skripsi). Bogor: FMIPA. IPB.

Winarno, WP. 1997. Kimia Pangan dan Gizi. Jakarta. Gramedia. 